IJMS 18 (1), 31-47 (2011)

\title{
CHOOSING A NEWSPAPER FOR ADVERTISING USING THE WEIGHTED EXPOSURE MATRIX METHOD - A MALAYSIA CASE STUDY
}

\author{
P. D. D. DOMINIC \\ K. S. SAVITA \\ P. A. EMELIA AKASHAH \\ Computer and Information Science Department \\ Universiti Teknologi Petronas, Malaysia
}

\begin{abstract}
Advertising is one of the marketing strategies to promote products to consumers. Many advertising vehicles are available offering interesting advertising packages. The key objective of this study is to find which Malaysian newspaper is the better option to advertise your products or services in the newspaper so as to maximize your reach of the audience. Here the researchers selected two popular newspapers - The Star and Harian Metro - for this research and analysed them based on the lowest cost for advertising per 1000 exposures using the weighted exposure matrix method. The result of this study shows that important factors such as cost, reach, frequency and target audience play important roles in selecting the best newspaper as the preferred advertisement vehicle.
\end{abstract}

Keywords: Advertisement; cost per thousand exposures; media, newspaper.

\begin{abstract}
Abstrak
Salah satu strategi untuk mempromosikan produk kepada pengguna adalah melalui kaedah pengiklanan. Pelbagai jenis pengiklanan yang ditawarkan kepada syarikat untuk mempromosikan produk mereka termasuk yang menawarkan pelbagai pakej yang menarik. Menerusi kajian ini, kaedah matriks pemberat pendedahan akan digunakan bagi tujuan untuk mendapatkan alternatif terbaik untuk membuat pemilihan bagi menentukan media mana yang paling baik untuk dipilih sebagai medium pengiklanan. Dua jenis surat khabar di Malaysia (The Star dan Harian Metro) dipilih sebagai sampel dan dengan menggunakan kaedah matriks pemberat pendedahan, perbandingan akan dibuat untuk menentukan pilihan yang
\end{abstract}


terbaik berdasarkan kos terendah. Objektif kajian ini adalah untuk mencari media di Malaysia yang menawarkan kos terendah per 1000 pendedahan bagi tujuan pengiklanan.

Kata kunci: Pengiklanan, kos per 1000 pendedahan, media, surat khabar.

\section{Introduction}

Advertising is one of the most important factors in our society and modern economy to boost the sales of the company (Tellis, 2003). David and Kim (2000) stated that advertisements can be placed in any type of media; printed, electronic or web. Tellis (2003) suggested that in a single day consumers will see at least 100 to 1000 advertisements from various sources.

One of the marketing strategies to sell products to consumers is through advertising. Tellis (2003) reported that advertising could influence one's thought, decision, preference and also attitude. With such a big impact on the consumers, companies are willing to pay big amounts of money in order to get their advertisements placed in any of their preferred media. Companies that produce or sell many types of products or provide services are most likely to advertise more. As a result, the advertising cost that they need to bear will be huge. According to Philip (2003), this can be considered as one of the crucial investments before they gain profit from their products or services.

Tellis (2003) stated that advertisements will and can create new demands as well as needs from the current and prospective customers. Generally, consumers will purchase goods that they see in advertisements based on the attractiveness of the information presented. Not only that, it may lead to possibilities of purchasing the products or services due to the persuasion and the trust built via the advertisements.

Media companies will always try to offer attractive advertising packages. For example, it is cheaper to choose a package with several numbers of exposures rather than to choose the one with only onetime exposure. Krugman (as cited in Tellis, 2003) suggested that a few exposures (e.g. three exposures) may be enough for an advertisement to be effective since the first advertisement will draw the attention of the consumers, the second will make the consumers like the brand or product being advertised and the third will persuade consumers to buy the advertised product.

32 IJMS 18 (1), 31-47 (2011) 


\section{Literature Review}

The marketing programme is most important for any organization to promote their products; so choosing the right vehicle to communicate the promotional message should be carefully considered (David \& Kim, 2000). Information can be generated from the advertisement which will benefit the consumers. However, among all the advertisements that the public see out there, some will be misleading (Philip, 2003). Since the study will be carried out on the advertisements in Malaysian newspapers, the most important factor to consider is the demand for the newspapers themselves. The newspapers with the most number of readerships will have a strong demand for advertisements (Jonas \& Sten, 2000). Newspaper companies definitely can generate profit out of this endeavor. Newspapers with higher number of readership will charge more for their advertising space, yet more companies would still request for their advertising service (Jonas \& Sten, 2000).

The total expenditure in the Malaysian advertising market for the year 2008 had increased to RM 6.2 billion; a total growth of 13 percent compared to the previous year (Liew, 2009). Among the entire advertising media in Malaysia (television, newspapers, point-ofsale, internet, magazines etc.), newspapers have become the biggest contributor to the growth of the advertising market in the country, with shares of 54 percent and with a growth of 8.3 percent (Liew, 2009). This growth is a good sign for the media, but at the same time it gives some impact to any organization that needs to spend more of their budget for advertising, since the cost of advertisement is increasing. The organization with a limited budget allocated for advertising purposes would have to consider the lowest option available, especially in choosing the newspaper which offers the best package at the lowest rate.

Table 1

Total Advertising Expenditure by Media in Malaysia in 2007 and 2008

\begin{tabular}{lccccc}
\hline \multirow{2}{*}{ Media } & \multicolumn{2}{c}{2007} & \multicolumn{2}{c}{2008} & \multirow{2}{*}{ Growth Rate } \\
\cline { 2 - 5 } & $\left(\mathrm{RM}^{\prime} 000\right)$ & Share & $\left(\mathrm{RM}^{\prime} 000\right)$ & Share & \\
\hline Newspapers & $3,065,289$ & $56.1 \%$ & $3,320,832$ & $53.9 \%$ & $8.3 \%$ \\
Television & $1,799,079$ & $32.9 \%$ & $2,161,195$ & $35.1 \%$ & $20.1 \%$ \\
Radio & 241,088 & $4.4 \%$ & 291,518 & $4.7 \%$ & $20.9 \%$ \\
\hline
\end{tabular}

(continued) 


\begin{tabular}{lccccc}
\hline \multirow{2}{*}{ Media } & \multicolumn{2}{c}{2007} & \multicolumn{2}{c}{2008} & \multirow{2}{*}{ Growth Rate } \\
\cline { 2 - 5 } & $\left(\mathrm{RM}^{\prime} 000\right)$ & Share & $\left(\mathrm{RM}^{\prime} 000\right)$ & Share & \\
\hline Magazines & 166,164 & $3.0 \%$ & 156,117 & $2.5 \%$ & $-6.0 \%$ \\
Outdoor & 108,162 & $2.0 \%$ & 95,892 & $1.6 \%$ & $-11.3 \%$ \\
Point of Sales & 57,855 & $1.1 \%$ & 73,935 & $1.2 \%$ & $27.8 \%$ \\
Internet & $\mathrm{N} / \mathrm{A}$ & $\mathrm{N} / \mathrm{A}$ & 32,110 & $0.5 \%$ & - \\
Cinema & 26,267 & $0.5 \%$ & 27,398 & $0.5 \%$ & $4.3 \%$ \\
Total & $5,463,904$ & $100.0 \%$ & $6,158,995$ & $100.0 \%$ & $12.7 \%$ \\
\hline
\end{tabular}

Source: Liew, 2009

Table 1 shows the advertising expenditure by media in Malaysia in 2007 and 2008. We can understand that, every year the amount of investment for advertising expenditure is increasing. Also the above table shows that interest on television and radio advertisements is increasing compared to newspaper and magazine advertisements. Malaysia has quite a number of newspapers; Utusan Malaysia, Berita Harian, Harian Metro, The Star, and New Straits Times to name a few. The statistics for Bahasa Malaysia and English dailies ("Malaysia Newspaper", 2009) based on the survey for Malaysian Newspaper Readership for the year 2007 is as below:

\section{Bahasa Malaysia dailies:}

1. Harian Metro - 1.98 million readers

2. Berita Harian - 1.27 million readers

3. Utusan Malaysia - 1.10 million readers

\section{English dailies:}

1. The Star -1.12 million readers

2. New Straits Times - 0.33 million readers

Several general environmental factors may affect a firm's decisions in any media selection situation - whether in domestic or non-domestic markets (Dominic, Savita \& Akashah, 2009). The most frequently mentioned factors are type of product, target audience, budget size, cost efficiency, reach and frequency, and competitors' advertising (Coulter \& Sarkis, 2005). All the factors will be discussed below as stated in Dominic et al., 2009.

34 IJMS 18 (1), 31-47 (2011) 


\section{A. Target Audience}

In every media selection situation, the task of the advertiser is to develop a definite understanding of the market for their product (Nowak, Cameron \& Krugman,1993). To select the medium to carry the message after identifying the group of consumers to whom the message is to be targeted is important for every advertisement. This, however, may not be as simple as it seems especially when it is recognized that an optimal medium may not be available in some areas of the world (Jeannet \& Hennessey, 2004).

\section{B. Budget Size}

Advertising budget allocations may limit the flexibility of media choice in both domestic and non-domestic markets. Often the budget is not large enough to allow year-round advertising (Sissors \& Baron, 2002). Sometimes the budget may have to be split between markets, taking into account the communication objectives of the company or brand.

\section{Reach Frequency}

This factor refers to the number or the percentage of a population group exposed to a media schedule within a given period of time. The frequency is the number of times people (or homes) are exposed to an advertising message, an advertising campaign, or a specific media vehicle. The period of issuance of a publication may be on daily, weekly or monthly basis. Closely tied to media budget is the reach and frequency factor. When a media budget is very high, it may be possible to achieve both high reach and high frequency. Often, however, the cost is too high to do both (Sissors \& Baron, 2002). In many countries, a broad variety of national, regional and international media must be used to reach the majority of the market. However, this tactic often spreads the advertising budget too thin, thereby sacrificing frequency (Dahringer \& Muhlbacher, 1991).

\section{Cost Efficiency}

Sissors and Baron (2002) state that most advertisers attempt to select the medium that can deliver their message to their prospective customers with a minimum of waste or reach their target audience most effectively and efficiently (Belch \& Belch, 2007; Mueller, 2004). In general, a non-domestic campaign is more expensive than a domestic one.

IJMS 18 (1), 31-47 (2011) 35 


\section{E. Impact}

The impact factor can be defined as the qualitative value of an exposure or effect through a given media to the customers based on the placement of the advertisement in a newspaper. However, the researcher had taken the impact factor as a quantitative factor for calculation in percentage.

\section{F. Total Number of Exposure}

This is the reach multiplied by the average frequency; this measure is referred to as the gross rating points.

Total number of exposure $=$ Reach $X$ Average frequency

\section{G. Weighted Number of Exposure}

This is the reach multiplied by average frequency multiplied by average impact.

Weighted number of exposure $=$ Reach $\mathrm{X}$ Average frequency $\mathrm{X}$ Average impact

\section{Methodology}

In our survey, we considered both categories (Bahasa Malaysia and English dailies) which have the highest number of readers. The study was carried out for Harian Metro and The Star. For this research, the properties of the newspapers that were taken into consideration are: (1) National Edition, (2) Main Paper (3) Run On Pages (ROP) Display, and (4) Black and White Printing. Based on the ROP concept, the advert will be placed at any available space in the main paper, except for the first page of the paper. If a specified page of the paper is chosen, a loading fee will be charged. The insertion fee and loading fee of the advert need to be paid in full where the required page also needs to be booked in advance; at least 1-2 weeks before the printing date.

Data collection was conducted through distribution of questionnaires to potential newspaper readers. The respondents were chosen based on random sampling where 120 respondents participated in the survey; 50 of whom were females and 70 were males of different age groups, educational background and level of education. The minimum

36 IJMS 18 (1), 31-47 (2011) 
level of education among the participants is Diploma. Type of news and advertisements placed in the papers are the primary factors that lead the readers to purchase the newspapers and read the advertisements more than once. According to the participants of the survey, the headlines and news in Harian Metro are more eye-catching and interesting respectively. Moreover, the types of advertisements in Harian Metro are much more to the liking of the audience/readers. The level of education is the secondary factor for the readers to choose the Bahasa Malaysia newspaper. Some of them preferred the national language as it is easier to read and understand the content of the news or advertisements. The researchers generalized that the readers chose their preferred newspapers based on the language used in the paper, apart from the types of advertisements.

\section{Numerical Illustration}

The objective of this paper is to identify which newspaper - The Star or Harian Metro - is as the most cost-effective newspaper based on the placement of the advertisement using the weighted exposure matrix method in order to achieve the lowest cost per thousand exposures.

Cost $/ 1000$ exposures $(\mathrm{CPTE})=($ Cost incurred $/$ weighted exposures $)$ $/ 1000$

\section{Facts and assumptions for this research:}

1. The target population size is 120 .

2. Number of The Star readers is 50 .

3. Number of Harian Metro readers is 70.

The following list of variables can be identified:

Cost of ad on ROP of Main National edition front page quarter size (black), C11

Cost of ad on ROP of Main National edition front page half size (black), C21

Cost of ad on ROP of Main National edition front page full size (black), C31 
Cost of ad on ROP of Main National edition middle pages quarter size (black), C12

Cost of ad on ROP of Main National edition middle pages half size (black), C22

Cost of ad on ROP of Main National edition middle pages full size (black), C32

Cost of ad on ROP of Main National edition last page quarter size (black), C13

Cost of ad on ROP of Main National edition last page half size (black), C23

Cost of ad on ROP of Main National edition last page full size (black), C33

Reach of the ad for each type $=\{R 11, R 12, \ldots \ldots, R 33\}$

Frequency of the ad for each type,$\{\mathrm{F} 11, \mathrm{~F} 12, \ldots . ., \mathrm{F} 33\}$

Impact of the ad, I

Weighted exposure of ad of each type \{WE11,WE22, ..., WE33\} Cost per 1000 exposures (CPTE)

\section{The Star}

The size of The Star newspaper is $37 \mathrm{~cm} * 8$ columns. Therefore, The Star newspaper is known as a Tabloid newspaper. Each of the column size is $3.3 \mathrm{~cm}$. The minimum column size of the advertisement is two columns. The calculation of quarter, half and full size advertisements is as follows:-

$$
\begin{aligned}
& \text { Quarter }=12 \mathrm{~cm} * 2 \text { columns } \\
& \text { Half }=18.5 \mathrm{~cm} * 4 \text { columns } \\
& \text { Full }=37 \mathrm{~cm} * 8 \text { columns }
\end{aligned}
$$

The basic rate for an advertisement is RM63.90 based on the four properties of the papers discussed earlier. The price excludes the government tax of $5 \%$ and a loading fee as the advertisement will be placed at any available space in any of the newspaper pages.

38 IJMS 18 (1), 31-47 (2011) 
Reach, frequency and cost of advertising for The Star are as given below in Table 2, Table 3 and Table 4 respectively.

Table 2

'The Star' Reach Matrix

\begin{tabular}{lccc}
\hline & ROP (Front page) & ROP (Middle page) & ROP (Last page) \\
\hline Quarter page & 20 & 5 & 8 \\
Half page & 25 & 7 & 10 \\
Full page & 30 & 9 & 11 \\
\hline
\end{tabular}

In Table 2, the description of the value 20 in row 1 , column 1 is, out of 50 target audience the possibility of reach is 20 . Likewise, based on the position of the advertisement in the newspaper and the size of the advertisement the reach may vary from 5 to 30 .

Table 3

'The Star' Frequency matrix

\begin{tabular}{lccc}
\hline & ROP (Front page) & ROP (Middle page) & ROP (Last page) \\
\hline Quarter page & 3 & 1 & 2 \\
Half page & 4 & 2 & 3 \\
Full page & 5 & 3 & 4 \\
\hline
\end{tabular}

In Table 3, the value 3 in row 1, column 1 represents the number of times a reader of a specific newspaper may view the advertisement at any given time in a period of one day. Likewise, based on the position on the newspaper and the size of the advertisement the number of times the advertisement is viewed may vary from 1 to 5 .

Table 4

'The Star' Exposure Matrix

\begin{tabular}{lccc}
\hline & ROP (Front page) & ROP (Middle page) & ROP (Last page) \\
\hline Quarter page & 60 & 5 & 16 \\
Half page & 100 & 14 & 30 \\
Full page & 150 & 18 & 44 \\
\hline
\end{tabular}

In Table 4 , the value 60 in row, 1 column 1 is calculated from Tables 2 and 3. It is simply the multiplication of 20 and 3. Likewise, based on 
the position in the newspaper and the size of the advertisement the exposures vary from 5 to 150 .

The next step is to calculate the weighted exposure for the advertisement in the newspaper. For that the researchers assumed an impact (I). For The Star, it is assumed as 0.75 .

Table 5

'The Star' Weighted Exposure Matrix

\begin{tabular}{lccc}
\hline & ROP (Front page) & ROP (Middle page) & ROP (Last page) \\
\hline Quarter page & 45 & 3.75 & 12 \\
Half page & 75 & 10.5 & 22.5 \\
Full page & 112.5 & 13.5 & 33 \\
\hline
\end{tabular}

In Table 5, the value 45 in row 1 , column 1 is calculated from Table 4 and the impact value for The Star newspaper is $0.75\left(60^{*} 0.75=45\right)$. Likewise, the remaining values were calculated and presented in Table 5.

Table 6

'The Star' Cost (RM) of the Advertisement Matrix

\begin{tabular}{lccc}
\hline & ROP (Front page) & ROP (Middle page) & ROP (Last page) \\
\hline Quarter page & $1,610.28$ & $1,610.28$ & $1,610.28$ \\
Half page & $4,965.03$ & $4,965.03$ & $4,965.03$ \\
Full page & $19,860.12$ & $19,860.12$ & $19,860.12$ \\
\hline
\end{tabular}

In Table 6, the value 1610.28 in row 1 , column 1 is calculated from the standard sizes of the advertisements in the newspaper for a quartersize page multiplied by the basic rate for an advertisement in The Star newspaper with an additional amount of $5 \%$ tax leading to the above value. A similar calculation is done for half page and full page.

For example, Quarter $=(12 \mathrm{~cm} * 2$ columns * RM63.90 $)+5 \%$ GST $=$ RM1,610.28

Half $=(18.5 \mathrm{~cm} * 4$ columns $*$ RM63.90 $)+5 \%$ GST $=$ RM4 4965.03

Full $=(37 \mathrm{~cm} * 8$ columns $*$ RM63.90 $)+5 \%$ GST $=$ RM19, 860.12

40 IJMS 18 (1), 31-47 (2011) 


\section{Harian Metro}

The size of the Harian Metro newspaper is $33 \mathrm{~cm} * 8$ columns. Harian Metro is also known as a tabloid newspaper. Each column size is $3.0 \mathrm{~cm}$. The minimum size of the advert is $30 \mathrm{~cm}$.

The calculation for of quarter, half and full size ads are as follows:-

$$
\begin{aligned}
& \text { Quarter }=17 \mathrm{~cm} * 4 \text { columns } \\
& \text { Half }=17 \mathrm{~cm} * 8 \text { columns } \\
& \text { Full }=33 \mathrm{~cm} * 8 \text { columns }
\end{aligned}
$$

The basic rate for an advertisement is RM41.00 based on the four properties of the papers discussed earlier. The price excludes the government tax of $5 \%$ and a loading fee as the ad will be placed at any available space in any of the newspaper pages.

Reach, frequency and cost of advertising for Harian Metro are as given below in Table 7, Table 8 and Table 9 respectively.

Table 7

'Harian Metro' Reach Matrix

\begin{tabular}{lccc}
\hline & ROP (Front page) & ROP (Middle page) & ROP (Last page) \\
\hline Quarter page & 25 & 5 & 10 \\
Half page & 35 & 10 & 15 \\
Full page & 40 & 10 & 20 \\
\hline
\end{tabular}

In Table 7 , the description for the value 25 in row 1 , column 1 is, out of 70 target audience the possibility of reach is 25 . Likewise, based on the position of the advert in the newspaper and the size of the advertisement the reach may vary from 5 to 40 .

Table 8

'Harian Metro' Frequency Matrix

\begin{tabular}{lccc}
\hline & ROP (Front page) & ROP (Middle page) & ROP (Last page) \\
\hline Quarter page & 3 & 1 & 2 \\
Half page & 4 & 2 & 3 \\
Full page & 5 & 3 & 4 \\
\hline
\end{tabular}

IJMS 18 (1), 31-47 (2011) 41 
In Table 8 , the value 3 in row 1 , column 1 represents the number of times a reader of a specific newspaper may view the advertisement at any given time in a period of one day. Likewise, based on the position on the newspaper and the size of the advertisement the number of times the advertisement is viewed may vary from 1 to 5 .

Table 9

'Harian' Metro Exposure Matrix

\begin{tabular}{lccc}
\hline & ROP (Front page) & ROP (Middle page) & ROP (Last page) \\
\hline Quarter page & 75 & 5 & 20 \\
Half page & 140 & 20 & 45 \\
Full page & 200 & 30 & 80 \\
\hline
\end{tabular}

In Table 9, the value 75 in the row 1 , column 1 is calculated based on Tables 7 and 8. It is simply the multiplication of 25 and 3 . Likewise, based on the position in the newspaper and the size of the advertisement the exposures vary from 5 to 200 .

The next step is to calculate the weighted exposure for the advertisement in the newspaper. For that the researchers assumed an impact (I). Here, for Harian Metro, it is assumed as 0.90 .

Table 10

'Harian' Metro Weighted Exposure Matrix

\begin{tabular}{lccc}
\hline & ROP (Front page) & ROP (Middle page) & ROP (Last page) \\
\hline Quarter page & 67.5 & 4.5 & 18 \\
Half page & 126 & 18 & 40.5 \\
Full page & 180 & 27 & 72 \\
\hline
\end{tabular}

In Table 10, the value 67.5 in row 1 , column 1 is calculated from Table 9 and the impact value for the Harian Metro newspaper is $0.90\left(75^{*} 0.90=\right.$ 67.5). Likewise, the remaining values were calculated and presented in Table 10.

In Table 11, the value 2927.40 in row 1, column 1 is calculated from the standard sizes of the advertisements in the newspaper for a quartersize page multiplied by the basic rate for an advertisement in the

42 IJMS 18 (1), 31-47 (2011) 
Harian Metro newspaper with an additional amount of 5\% tax leading to the above value. A similar calculation is done for half page and full page.

Table 11

'Harian' Metro Cost (RM) of the Advertisement Matrix

\begin{tabular}{lccc}
\hline & ROP (Front page) & ROP (Middle page) & ROP (Last page) \\
\hline Quarter page & $2,927.40$ & $2,927.40$ & $2,927.40$ \\
Half page & $5,854.80$ & $5,854.80$ & $5,854.80$ \\
Full page & $11,362.20$ & $11,362.20$ & $11,362.20$ \\
\hline
\end{tabular}

For example, Quarter $=(17 \mathrm{~cm} * 4$ columns $*$ RM41.00 $)+5 \%$ GST $=$ RM2,927.40

$$
\begin{aligned}
& \text { Half }=(17 \mathrm{~cm} * 8 \text { columns } * \text { RM41.00 })+5 \% \text { GST }=\text { RM5,854.80 } \\
& \text { Full }=\left(33 \mathrm{~cm}^{*} 8 \text { columns } * \text { RM41.00 }\right)+5 \% \text { GST }=\text { RM11,362.20 }
\end{aligned}
$$

\section{Cost comparison between The Star and Harian Metro}

Consider first page quarter size alone:-

\section{The Star}

Weighted exposure

Cost incurred

Cost incurred for that exposure

Cost/ 1000 exposure

\section{Harian Metro}

Weighted exposure

Cost incurred

Cost incurred for that exposure

Cost/ 1000 exposure

$$
\begin{aligned}
& =45(\text { Table } 5) \\
& =\text { RM1,610.28 }(\text { Table } 6) \\
& =1,610.28 / 45=\text { RM } 35.78 \\
& =35.78 / 1000=\text { RM } 0.036
\end{aligned}
$$

$=67.5($ Table 10$)$

= RM 2,927.40 (Table 11)

$=2,927.40 / 67.5=\mathrm{RM} 43.37$

$=43.37 / 1000=\mathrm{RM} 0.043$

IJMS 18 (1), 31-47 (2011) 43 
A similar calculation for all the eight possibilities of positions and sizes are calculated and presented in the Table 12(a) for The Star and in Table 12(b) for Harian Metro.

Table 12(a)

CPTE for 'The Star'

\begin{tabular}{lccc}
\hline & ROP (Front page) & ROP (Middle page) & ROP (Last page) \\
\hline Quarter page & 0.036 & 0.430 & 0.134 \\
Half page & 0.066 & 0.473 & 0.221 \\
Full page & 0.177 & 1.471 & 0.601 \\
\hline
\end{tabular}

Table 12(b)

CPTE for 'Harian Metro'

\begin{tabular}{lccc}
\hline & ROP (Front page) & ROP (Middle page) & ROP (Last page) \\
\hline Quarter page & 0.043 & 0.065 & 0.016 \\
Half page & 0.046 & 0.325 & 0.144 \\
Full page & 0.063 & 0.043 & 0.158 \\
\hline
\end{tabular}

Table 12(c)

Optimal Choices of 'The Star' and 'Harian Metro'

\begin{tabular}{llll}
\hline & ROP (Front page) & ROP (Middle page) & ROP (Last page) \\
\hline Quarter page & The Star & Harian Metro & Harian Metro \\
Half page & Harian Metro & Harian Metro & Harian Metro \\
Full page & Harian Metro & Harian Metro & Harian Metro \\
\hline
\end{tabular}

In Table 12(c), the decision to select The Star was based on the comparison between the values on Tables 12(a) and 12(b). The lower CPTE is selected for implementation. For example, the CPTE for a quarter page in the front page of The Star is 0.036 and the CPTE for a quarter page in the front page of Harian Metro is 0.043. The lower value is for The Star. According to Table 12(c), Harian Metro provides less cost per thousand exposures in all different sizes and different locations except for quarter size in the front page.

44 IJMS 18 (1), 31-47 (2011) 
For a given budget amount, the management has to make a tradeoff decision between the number of exposures inserted in any lowest print newspaper and the budget to be allocated for advertisement in the printed media.

No. of exposures for a given period $=$ Budget allocated ${ }^{*}$ Weighted exposure/ Cost incurred.

For a given budget amount of RM 100,000, the number of exposures for The Star and Harian Metro on the different environments are calculated as below:

Table 13

Cost Comparison between 'The Star' and 'Harian Metro' for any Budget

\begin{tabular}{lcc}
\hline \multicolumn{1}{c}{ Features } & \multicolumn{1}{c}{ The Star } & Harian Metro \\
\hline Front page Quarter size ad & $100000 * 45 / 1,610.28=2,795$ & $100000 * 67.5 / 2,927.40=2306$ \\
Middle page Quarter size ad & $100000 * 3.75 / 1,610.28=233$ & $100000 * 4.5 / 2,927.40=154$ \\
Last page Quarter size ad & $100000 * 12 / 1,610.28=745$ & $100000 * 18 / 2,927.40=615$ \\
Front page Half size ad & $100000 * 75 / 4,965.08=1,511$ & $100000 * 126 / 5,854.80=2152$ \\
Middle page Half size ad & $100000 * 10.5 / 4,965.08=212$ & $100000 * 18 / 5,854.80=307$ \\
Last page Half size ad & $100000 * 22.5 / 4,965.08=453$ & $100000 * 40.5 / 5,854.80=692$ \\
Front page Full size ad & $100000 * 112.5 / 19,860.12=567$ & $100000 * 180 / 11,362.20=1584$ \\
Middle page Full size ad & $100000 * 13.5 / 19,860.12=68$ & $100000 * 27 / 11,362.20=238$ \\
Last page Full size ad & $100000 * 33 / 19,860.12=166$ & $100000 * 72 / 11,362.20=634$ \\
\hline
\end{tabular}

Based on Table 13, we understand Harian Metro generates more exposures than The Star within the given budget of RM100,000 except for quarter size in front page, middle page and last page. From the above calculation, the decision makers should be able to identify the page and the size of the advertisement for the given budget. Moreover, if the company considers exposures as the criteria, then placing the ad in the front page half size advertisement generates more exposures for Harian Metro. On the other hand, for The Star, the best value for money would be an ad in quarter size also on the front pages. As discussed earlier, the researchers have generalized that the readers chose their preferred newspapers based on the language used in the paper - apart from the type of advertisements in the newspaper that they are looking for (e. g. job vacancies advertisement). These 
are among the factors that need to be considered by the company in choosing the best option for advertising apart from the cost of the advertising itself.

\section{Conclusion}

The result of this study shows that important factors such as cost, reach, frequency and target audience play important roles in selecting the best newspaper as the preferred advertisement vehicle. The method presented in this research paper offers an efficient alternative to choose the lowest cost of printed media advertisement per thousand exposures. This method could be used by companies to prepare their advertising budgets to choose the newspaper that offers the best package for their advertisement placement. The study on internet advertising could be future research as the option for the companies to place their advertisements.

\section{References}

Belch, G., \& Belch, M. (2007). Advertising and promotion: An integrated marketing communications perspective (7th ed.). New York: McGraw-Hill.

Coulter, K., \& Sarkis, J. (2005). Development of a media selection model using the analytic network process. International Journal of Advertising, 24(2), 193-215.

David, S. W., \& Kim, S. F. (2000). Cultural values and advertising in Malaysia: Views from the Industry. Asia Pacific Journal of Marketing and Logistics, 12, 3-16.

Dahringer, L., \& Muhlbacher, H. (1991). International marketing: A global perspective. Reading, MA: Addition-Wesley.

Dominic, P. D. D., Sugathan, K. S., \& Akashah, E. (2009). Choosing among media alternatives for advertising: A case study. Proceeding of First International SEARCH Conference.

Jeannet, J. P., \& Hennessey, H. D. (2004). Global marketing strategies (6th ed.). Boston, MA: Houghton Mifflin.

Jonas, H., \& Sten, N. (2000). Price competition, advertising and media market concentration. Retrieved from http://www.ne.su.se/ paper/wp00_03.pdf

Liew, M. (2009). Malaysia records 13\% growth in advertising in 2008. Retrieved from http://my.nielsen.com/news/20090212.shtml

Malaysia Newspaper Readership. (2009). Retrieved from http://www. geocities.com/Malaysia_newspaper

46 IJMS 18 (1), 31-47 (2011) 
Mueller, B. (2004). Dynamics of international advertising: Theoretical and practical perspective. New York: Peter Lang Publishing.

Nowak, G. J., Cameron, G. T., \& Krugman, D. M. (1993). How local advertisers choose and use advertising media. Journal of Advertising Research, 33(6), 39-49.

Philip, N. (2003). Advertising as information. The Journal of Political Economy, Retrieved from http://time.dufe.edu.cn/ jingjiwencong/waiwenziliao/20031148365645706.pdf

Sissors, J. Z., \& Baron, R. B. (2002). Advertising media planning (6th ed.). Chicago, IL: McGraw-Hill.

Tellis, G. J. (2003). Effective advertising: Understanding when, how and why advertising works (Marketing for a new century). Thousand Oaks: Sage Publications. 